\title{
Extended Single Nucleotide Polymorphism and Haplotype Analysis of the elastin Gene in Caucasians with Intracranial Aneurysms Provides Evidence for Racially/Ethnically Based Differences
}

\author{
Dietmar Krexa Inke R. König ${ }^{c} \quad$ Andreas Ziegler ${ }^{c}$ Hans K. Schackert $^{\mathrm{b}}$ \\ Gabriele Schackert ${ }^{a}$
}

Departments of a Neurosurgery and ${ }^{\text {b }}$ Surgical Research, University Hospital Carl Gustav Carus, University of Technology, Dresden, and 'Institute of Medical Biometry and Statistics, University at Lübeck, Lübeck, Germany

\section{Key Words}

Intracranial aneurysm • Polymorphism - Genetics ·

Elastin · Ethnology

\begin{abstract}
Background: There is growing evidence that genetic variants have an impact on the pathogenesis of intracranial aneurysm (IA). Recently, the genetic locus around the elastin gene ( $7 q 11)$ has been identified as linked to IA in a Japanese population. Our aim was to confirm these results in Caucasian populations. Methods: We conducted a case-control study in 120 Caucasian patients with IA and 172 controls to investigate 8 single nucleotide polymorphisms (SNPs) and various haplotypes within the elastin gene, which were frequently found and associated with the phenotype in the Japanese populations. Real-time PCR and melting curve analysis were used for the detection of genotypes. Results: Allele frequencies and genotypes were equally distributed between Caucasian cases and controls. We failed to identify haplotypes that are associated with the phenotype in our population, which is in contrast to the Japanese study. However, allele frequencies in control populations
\end{abstract}

differ between Caucasians and Japanese. Conclusions: We found no association between SNPs and haplotypes of the elastin gene and the occurrence of IA in our Caucasian populations. However, our data provide strong evidence for racial/ethnic differences in the association of SNP and specific haplotypes of the elastin gene with the phenotype. There might be other genetic variants of the elastin gene associated with IA in Caucasians.

Copyright @ 2004 S. Karger AG, Basel

\section{Introduction}

Ruptured intracranial aneurysm (IA) is one of the most serious forms of cerebrovascular disease, with a mortality approaching $40 \%$ in spite of modern treatment modalities [1]. Although such risk factors as cigarette smoking, elevated arterial blood pressure and female gender have been identified [2-4], little is yet known about the molecular pathology of aneurysm genesis. Recent studies point to the importance of remodeling processes in the extracellular matrix (ECM) of arterial vessels and aneurysm walls [5]. The ECM is a dynamic network of proteins and proteoglycans that is essential for structural maintenance in

\begin{tabular}{ll}
\hline KARGER & ( ) 2004 S. Karger AG, Basel \\
Fax +4161306 1234 & \\
$\begin{array}{l}\text { E-Mail karger@karger.ch } \\
\text { www.karger.com }\end{array}$ & $\begin{array}{l}\text { Accessible online at: } \\
\text { www.karger.com/ced }\end{array}$
\end{tabular}

Dr. Dietmar Krex

Department of Neurosurgery, Carl Gustav Carus University Hospital

University of Technology, Fetscherstrasse 74

DE-01307 Dresden (Germany)

Tel. +49 351458 2886, Fax +49 351458 4304, E-Mail krex@rcs.urz.tu-dresden.de 
many tissues and relies on a balance between synthesis and degradation of ECM proteins. The content and threedimensional organization of elastin fibers, an essential component of the ECM of vessel walls, was found to be altered in the wall of cerebral aneurysms [6]. In a gene expression analysis of a single IA, elastin was among the most abundantly expressed tags, indicating that in this IA significant tissue remodeling was taking place [7]. These data are supported by previous findings about elastase, which specifically degrades elastin molecules and which has been successfully used in vitro and in animal models to induce aneurysm formation [8-10]. In addition, spontaneous development of cerebral aneurysms in the female heterozygous Blotchy mouse, which is characterized by a mild form of connective tissue disorder, supports the hypothesis that genetic variants resulting in defective elastin and collagen fiber synthesis are associated with cerebral aneurysm formation [11].

Recently, the first genome-wide linkage study for IA, conducted in 104 affected Japanese sib pairs, has been published [12]. The best evidence of linkage has been found on chromosomes 5q22-31, 7q11 and 14q22, while the most pronounced effect has been reported at D7S2472, which is in the vicinity of the elastin gene. Therefore, the authors have performed a detailed analysis of the elastin gene and have detected 14 polymorphisms. None of these has been significantly associated with the phenotype ( $p>0.05$ for each). However, haplotypes have been constructed, which revealed 3 pairs of polymorphisms, with intron 20 /intron 23 polymorphism as the one to be most closely associated $\left(\mathrm{p}=3.81 \times 10^{-6}\right)$ with the occurrence of IA.

We and others have provided evidence for racial/ethnic differences in the association of genetic variants with a phenotype by studying the endoglin gene [13] or in larger studies by analyzing the $M D R 1$ gene [14] or the fragile $\mathrm{X}$ syndrome $C G G$ repeat [15]. In the present study, we sought to confirm the Japanese findings in Caucasian populations. Therefore, in our study, Caucasian patients presenting with IA and healthy Caucasian controls were enrolled to allow us to investigate single nucleotide polymorphisms (SNPs) and haplotype frequencies. Our aims were to detect an association with the phenotype in Caucasians and to compare allele and haplotype frequencies between the Caucasian and Japanese populations.

\section{Material and Methods}

\section{Study Design}

We selected 8 out of the 14 polymorphisms identified in a Japanese study by Onda et al. [12] by the following criteria: all 3 SNPs located in the promoter region; all 3 SNPs leading to an amino acid exchange, and 2 SNPs with a frequency of $>0.1$ in the control population, which have rendered an account after haplotype construction. Knowing that allele frequencies of SNPs in populations of different ethnicity may vary considerably, we analyzed these 8 SNPs in a primary study group comprising 62 controls to determine their allele frequencies in a healthy Caucasian population. All detectable SNPs were investigated in a second study group comprising 120 cases and another 110 controls.

\section{Population}

The patient group consisted of 120 unrelated patients with IA [59 male and 61 female patients were consecutively recruited; their mean ages were 54 (range 27-74) and 55 (range 28-82) years, respectively].

All patients presented with at least 1 aneurysm, which was confirmed by cerebral angiography, and they were all operated on or treated by an endovascular approach in the Departments of Neurosurgery and Neuroradiology, respectively, at the University of Technology in Dresden. All patients were residents of the Dresden urban area. None had any family or personal history of subarachnoid hemorrhage, and none had polycystic kidney disease or any kind of connective tissue disease like Marfan or Ehlers-Danlos syndrome. The prevalence rates of the risk factors hypertension, cigarette smoking and diabetes mellitus among the patients were 20.8, 27.5 and $2.5 \%$, respectively.

The control group in the primary study group consisted of 62 anonymous, healthy blood donors enrolled from the same urban area. In the second study group, another 124 controls were enrolled. Because of its historical background, the city of Dresden is populated by a homogeneous Caucasian population. In general, blood donors are found in all social classes in Germany, and blood is donated exclusively on a voluntary basis. All potential blood donors are routinely screened for diseases by use of a questionnaire, RBC, WBC and liver function tests and assays for detection of infectious diseases. In addition to the Caucasian controls, we used a Japanese control group comprising 12 anonymous healthy Japanese individuals. This study was approved by the local ethics committee. Informed written consent for genetic analysis was obtained from all nonanonymous individuals.

\section{SNP Detection Using Real-Time PCR}

In our study, we used a real-time PCR-based approach to analyze 8 polymorphic sites. PCR was performed on a LightCycler ${ }^{\circledR}$ (Roche, Mannheim, Germany) using hybridization probes in combination with the LightCycler ${ }^{\circledR}$ DNA Master Hybridization Probes Kit (Roche). The principles of the LightCycler technology are described elsewhere $[16,17]$. The PCR primers and hybridization probes were commercially synthesized by TIB Molbiol (Berlin, Germany) and are summarized in table 1. After completion of PCR cycles, a melting curve analysis has to be performed to distinguish polymorphic alleles. The PCR conditions and the conditions used to generate melting curves are provided by the authors upon request. PCR and the melting procedure were determined in real time with the LightCycler instrument. Melting curves were analyzed by means of the 
Table 1. List of hybridization probes and PCR primers used in real-time PCR

\begin{tabular}{|c|c|c|c|c|}
\hline \multirow[t]{2}{*}{ Location } & & \multicolumn{2}{|l|}{ Hybridization probes } & PCR primer \\
\hline & & $5^{\prime}$ & & $5^{\prime}$ \\
\hline \multirow[t]{2}{*}{$-1042 \mathrm{C} \rightarrow \mathrm{T}$} & $\mathrm{S}$ & GGGCCCCACCTCCCTG & $\mathrm{F}$ & TGGTGTGGGCGCTAGCT \\
\hline & A & TCCCCCACAGGGCACCTGG & $\mathrm{R}$ & CTGTCCCCAGGGGCATCT \\
\hline \multirow[t]{2}{*}{$-972 \mathrm{G} \rightarrow \mathrm{A}$} & $\mathrm{S}$ & CCTATACCCAGCCCCACGCAG & $\mathrm{F}$ & GCTGGGCTGCCTGTCAGT \\
\hline & A & CCGCAGGGTCTGGTAAAAATCAGGCT & $\mathrm{R}$ & CTGTCCCCAGGGGCATCT \\
\hline \multirow[t]{2}{*}{$-38 \mathrm{C} \rightarrow \mathrm{T}$} & $\mathrm{S}$ & CACCTCATTTTATCCCCAAAGCC & $\mathrm{F}$ & CACAGCCGACGAGGCAA \\
\hline & A & GAAATGCCCCAGCCCGCTCTCC & $\mathrm{R}$ & CAGCAGGAGCAGGAGGACT \\
\hline \multirow{2}{*}{$\mathrm{IVS} 4+71 \mathrm{G} \rightarrow \mathrm{A}$} & $\mathrm{S}$ & CTAGTTTCCTTGTCCCATTCCCA & $\mathrm{F}$ & CAAGGCCTCGGAGCATTGA \\
\hline & A & CTGGGTAGGCTCCTCCСТCCCCAG & $\mathrm{R}$ & GGCCCCGGCCTACTCAT \\
\hline \multirow[t]{2}{*}{$212 \mathrm{C} \rightarrow \mathrm{T}$} & $\mathrm{S}$ & AGGCCAGCACCCACAAGCC & $\mathrm{F}$ & CATTTCCCACTCTGGGCCTA \\
\hline & A & TGGGTGTCAGCACTCACCTGCCCC & $\mathrm{R}$ & CCTGCACCCTTGTTCCAT \\
\hline \multirow[t]{2}{*}{$1264 \mathrm{G} \rightarrow \mathrm{A}$} & $\mathrm{S}$ & AGTCGCAGGTGTCCCTAGTGTC & $\mathrm{F}$ & GCCCAGCCTCTCTCACTGA \\
\hline & A & AGGTGTTCCCGGAGTCGGAGGTGTC & $\mathrm{R}$ & CССССАAСТССТСССТGA \\
\hline \multirow[t]{2}{*}{ IVS20 $+17 \mathrm{~T} \rightarrow \mathrm{C}$} & $\mathrm{S}$ & CCCCAGATGTGACTAAGGCTCAC & $\mathrm{F}$ & GTCCCGGGAGTTGGCATT \\
\hline & A & GCCСССАТСССТTCTCAACCCAT & $\mathrm{R}$ & СССССАAСТССТСССТGA \\
\hline \multirow{2}{*}{$\mathrm{IVS} 23+24 \mathrm{~T} \rightarrow \mathrm{C}$} & $\mathrm{S}$ & CCGCCACTGGCTCACG & $\mathrm{F}$ & АСТСТСТСАССССТТСТСТТСА \\
\hline & A & CCCAGTTTGGTAAGTCCCCCTCACC & $\mathrm{R}$ & AGAGCAGGGCACAGAAGAAA \\
\hline
\end{tabular}

$\mathrm{S}=$ Sensor probe $\mathrm{A}=$ anchor probe $\mathrm{F}=$ forward primer $\mathrm{R}=$ reverse primer.

LightCycler evaluation software. In particular, curves were plotted to the negative derivative of fluorescence $(\mathrm{F})$ with respect to temperature $(\mathrm{T})$, or $-\mathrm{dF} / \mathrm{dT}$, against temperature, which allows easier discrimination of melting curves.

\section{Statistical Methods}

Genotypes and allele frequencies of 8 SNPs were determined in the primary study group consisting of 62 controls. Only detectable SNPs were used for further analysis in the second study group comprising 120 cases and 110 controls. Cochrane-Armitage trend tests were performed to compare different genotype frequencies between the latter groups. Odds ratios and exact $95 \%$ confidence intervals are presented. The frequency of polymorphic alleles was compared between the Caucasian controls and the Japanese controls reported by Onda et al. [12] using Fisher's exact test with exact two-sided p values. Haplotype frequencies were estimated with the expectationmaximization algorithm [18]. Haplotype frequencies were compared between cases and controls calculating the $\chi^{2}$ statistic with simulated $\mathrm{p}$ values.

\section{Results}

In our primary study group, we could not detect the polymorphic allele in $4(-1042 \mathrm{C} \rightarrow \mathrm{T},-972 \mathrm{G} \rightarrow \mathrm{A},-38 \mathrm{C}$ $\rightarrow \mathrm{T}, 212 \mathrm{C} \rightarrow \mathrm{T}$; nomenclature according to den Dunnen and Antonarakis [19]) out of the 8 analyzed SNPs (table 2). These data were confirmed by analysis of these 4 SNPs in a group of 62 IA patients (data not shown).
Table 2. Genotype frequencies of 8 polymorphic sites within the elastin gene in the primary study group

\begin{tabular}{llrr}
\hline SNP & Genotype & \multicolumn{2}{c}{ Controls $(\mathrm{n}=62)$} \\
\cline { 3 - 4 } & & $\mathrm{n}$ & $\%$ \\
\hline$-1042 \mathrm{C} \rightarrow \mathrm{T}$ & $\mathrm{C} / \mathrm{C}$ & 62 & 100.0 \\
$-972 \mathrm{G} \rightarrow \mathrm{A}$ & $\mathrm{G} / \mathrm{G}$ & 62 & 100.0 \\
$-38 \mathrm{C} \rightarrow \mathrm{T}$ & $\mathrm{C} / \mathrm{C}$ & 62 & 100.0 \\
$\mathrm{IVS} 4+71 \mathrm{G} \rightarrow \mathrm{A}$ & $\mathrm{G} / \mathrm{G}$ & 55 & 88.7 \\
& $\mathrm{G} / \mathrm{A}$ & 7 & 11.3 \\
& $\mathrm{~A} / \mathrm{A}$ & 0 & \\
$212 \mathrm{C} \rightarrow \mathrm{T}$ & $\mathrm{C} / \mathrm{C}$ & 62 & 100.0 \\
$1264 \mathrm{G} \rightarrow \mathrm{A}$ & $\mathrm{G} / \mathrm{G}$ & 26 & 42.6 \\
& $\mathrm{G} / \mathrm{A}$ & 23 & 37.7 \\
$\mathrm{IVS} 20+17 \mathrm{~T} \rightarrow \mathrm{C}$ & $\mathrm{A} / \mathrm{A}$ & 12 & 19.7 \\
& $\mathrm{~T} / \mathrm{T}$ & 40 & 65.6 \\
$\mathrm{IVS} 23+24 \mathrm{~T} \rightarrow \mathrm{C}$ & $\mathrm{T} / \mathrm{C}$ & 20 & 32.8 \\
& $\mathrm{C} / \mathrm{C}$ & 1 & 1.6 \\
& T/T & 30 & 49.2 \\
& $\mathrm{~T} / \mathrm{C}$ & 24 & 39.3 \\
& $\mathrm{C} / \mathrm{C}$ & 7 & 11.5 \\
\hline
\end{tabular}


Table 3. Genotype frequencies of elastin polymorphisms in the second study group

\begin{tabular}{|c|c|c|c|c|c|c|c|c|}
\hline \multirow[t]{2}{*}{ Location } & \multirow{2}{*}{$\begin{array}{l}\text { Geno- } \\
\text { type }\end{array}$} & \multicolumn{2}{|c|}{ Cases $(n=120)$} & \multicolumn{2}{|c|}{ Controls $(\mathrm{n}=110)$} & \multirow[t]{2}{*}{ OR } & \multirow[t]{2}{*}{$95 \% \mathrm{CI}$} & \multirow{2}{*}{$\begin{array}{l}\text { Two- } \\
\text { sided } \\
\text { exact } p\end{array}$} \\
\hline & & $\mathrm{n}$ & $\%$ & $\mathrm{n}$ & $\%$ & & & \\
\hline \multirow[t]{3}{*}{$\mathrm{IVS} 4+71 \mathrm{G} \rightarrow \mathrm{A}$} & $\mathrm{G} / \mathrm{G}$ & 109 & 90.8 & 99 & 90.0 & & & \\
\hline & $\mathrm{G} / \mathrm{A}$ & 11 & 9.2 & 11 & 10.0 & 0.909 & $0.341-2.425$ & \\
\hline & $\mathrm{A} / \mathrm{A}$ & 0 & 0.0 & 0 & 0.0 & & & 1.000 \\
\hline \multirow[t]{3}{*}{$1264 \mathrm{G} \rightarrow \mathrm{A}$} & $\mathrm{G} / \mathrm{G}$ & 44 & 37.0 & 39 & 35.5 & & & \\
\hline & $\mathrm{G} / \mathrm{A}$ & 55 & 46.2 & 55 & 50.0 & 1.016 & $0.686-1.505$ & \\
\hline & $\mathrm{A} / \mathrm{A}$ & 20 & 16.8 & 16 & 14.5 & 1.031 & $0.470-2.265$ & 1.000 \\
\hline \multirow[t]{3}{*}{$\mathrm{IVS} 20+17 \mathrm{~T} \rightarrow \mathrm{C}$} & $\mathrm{T} / \mathrm{T}$ & 89 & 74.2 & 75 & 68.2 & & & \\
\hline & $\mathrm{T} / \mathrm{C}$ & 29 & 24.2 & 32 & 29.1 & 2,193 & $0.764-2.281$ & \\
\hline & $\mathrm{C} / \mathrm{C}$ & 2 & 1.7 & 3 & 2.7 & 4,811 & $0.584-5.201$ & 0.302 \\
\hline \multirow[t]{3}{*}{$\mathrm{IVS} 23+24 \mathrm{~T} \rightarrow \mathrm{C}$} & $\mathrm{T} / \mathrm{T}$ & 43 & 35.8 & 32 & 29.1 & & & \\
\hline & $\mathrm{T} / \mathrm{C}$ & 54 & 45.0 & 63 & 57.3 & 0.974 & $0.655-1.450$ & \\
\hline & $\mathrm{C} / \mathrm{C}$ & 23 & 19.2 & 15 & 13.6 & 0.950 & $0.429-2.102$ & 0.923 \\
\hline
\end{tabular}

OR = Odds ratio; $95 \% \mathrm{CI}=95 \%$ confidence interval.

Therefore, in our second study group, only the IVS4 + $71 \mathrm{G} \rightarrow \mathrm{A}, 1264 \mathrm{G} \rightarrow \mathrm{A}, \mathrm{IVS} 20+17 \mathrm{~T} \rightarrow \mathrm{C}$ and IVS23 + $24 \mathrm{~T} \rightarrow \mathrm{C}$ SNPs were investigated. Here, genotype frequencies at each of the 4 SNPs failed to show any association with the occurrence of IA in our Caucasian population (table 3).

The $-1042 \mathrm{C} \rightarrow \mathrm{T}$ and $-972 \mathrm{G} \rightarrow$ A polymorphisms in the promoter region of the elastin gene were detected in the Japanese control population with allele frequencies of 0.20 and 0.18 , respectively, by Onda et al. [12]. Interestingly, while we were not able to detect these common polymorphisms in our Caucasian populations, we did find them in our group of 12 anonymous healthy Japanese volunteers, indicating that our method was also suited to the identification of these particular polymorphic sites. Allele frequencies in this group were 0.41 and 0.58 for the polymorphic allele and hence different from those in our Caucasian control group $(\mathrm{p}<0.0001$; table 4$)$.

In addition, allele frequencies of the most prevalent polymorphic sites located in intron 4 (IVS4 $+71 \mathrm{G} \rightarrow \mathrm{A}$ ), exon $20(1264 \mathrm{G} \rightarrow \mathrm{A})$, intron $20(\mathrm{IVS} 20+17 \mathrm{~T} \rightarrow \mathrm{C})$ and intron 23 (IVS23 $+24 \mathrm{~T} \rightarrow \mathrm{C}$ ) in our Caucasian controls were compared with the frequencies in the Japanese controls reported by Onda et al. [12]. While there were no differences for the polymorphic alleles of the IVS20 + 17T $\rightarrow \mathrm{C}$ and IVS23 $+24 \mathrm{~T} \rightarrow \mathrm{C}$ polymorphisms $(\mathrm{p}=0.1238$ and 0.2306 , respectively), we detected differences at IVS4 $+71 \mathrm{G} \rightarrow \mathrm{A}(\mathrm{p}=0.0022)$ and $1264 \mathrm{G} \rightarrow \mathrm{A}(\mathrm{p}=0.0029)$,
Table 4. Allele frequencies of $-1042 \mathrm{C} \rightarrow \mathrm{T}$ and $-972 \mathrm{G} \rightarrow$ A polymorphisms in our Caucasian and Japanese control groups

\begin{tabular}{|c|c|c|c|c|c|c|}
\hline \multirow[t]{2}{*}{ SNP } & \multirow[t]{2}{*}{ Allele } & \multicolumn{2}{|c|}{$\begin{array}{l}\text { Caucasian } \\
\text { controls }(n=62)\end{array}$} & \multicolumn{2}{|c|}{$\begin{array}{l}\text { Japanese } \\
\text { controls }(\mathrm{n}=12)\end{array}$} & \multirow[t]{2}{*}{ Exact $p$} \\
\hline & & $\mathrm{n}$ & $\%$ & $\mathrm{n}$ & $\%$ & \\
\hline \multirow[t]{2}{*}{$-1042 \mathrm{C} \rightarrow \mathrm{T}$} & $\mathrm{C}$ & 124 & 100.0 & 14 & 58.3 & \\
\hline & $\mathrm{T}$ & 0 & 0.0 & 10 & 41.6 & $<0.0001$ \\
\hline \multirow[t]{2}{*}{$-972 \mathrm{G} \rightarrow \mathrm{A}$} & G & 124 & 100.0 & 10 & 41.6 & \\
\hline & A & 0 & 0.0 & 14 & 58.3 & $<0.0001$ \\
\hline
\end{tabular}

indicating a varied prevalence of these polymorphic sites also in these two ethnic groups.

Onda et al. [12] described the haplotype between the intron 20/intron 23 (IVS20 + 17T $\rightarrow$ C/IVS23 $+24 \mathrm{~T} \rightarrow \mathrm{C}$ ) polymorphism as strongly associated with the occurrence of IA in the Japanese population. This particular haplotype was not differently distributed between cases and controls in our Caucasian study population (table 5).

Moreover, haplotypes were constructed from those 4 frequent SNPs (IVS4 + 71G $\rightarrow$ A, 1264G $\rightarrow$ A, IVS20 + $17 \mathrm{~T} \rightarrow \mathrm{C}$ and IVS23 $+24 \mathrm{~T} \rightarrow \mathrm{C}$ ). Estimated haplotype frequencies between 119 cases and 110 controls were not significantly different (simulated $\mathrm{p}=0.1443$ ) as presented in table 6. 
Table 5. Pairwise haplotype frequencies of elastin IVS20 $+17 \mathrm{~T} \rightarrow$ C/IVS23 + 24T $\rightarrow$ C (Int20/Int23) SNPs (estimated by R)

\begin{tabular}{lllll}
\hline $\begin{array}{l}\text { Haplotype } \\
\text { Int20/Int23 }\end{array}$ & $\begin{array}{l}\text { Cases } \\
(\mathrm{n}=119), \%\end{array}$ & $\begin{array}{l}\text { Controls } \\
(\mathrm{n}=110), \%\end{array}$ & $\chi^{2}$ & $\begin{array}{l}\text { Simulated } \\
\mathrm{p}\end{array}$ \\
\hline TC & 4.0 & 0.0 & & \\
TT & 9.9 & 0.0 & & \\
CC & 37.2 & 25.0 & & \\
CT & 49.0 & 75.0 & 1.163 & 0.8229 \\
\hline
\end{tabular}

Haplotype counts were calculated from estimated haplotype frequencies. Hence, deviations between tables 5 and 6 may be the result of imprecise rounding.

Table 6. Frequencies of haplotypes constructed by SNPs of the elastin gene (estimated by R)

\begin{tabular}{lllll}
\hline Haplotype & $\begin{array}{l}\text { Cases } \\
(\mathrm{n}=119), \%\end{array}$ & $\begin{array}{l}\text { Controls } \\
(\mathrm{n}=110), \%\end{array}$ & $\chi^{2}$ & $\begin{array}{l}\text { Simulated } \\
\mathrm{p}\end{array}$ \\
\hline AACT & 0.5 & 0.8 & & \\
AGCC & 0.0 & 0.6 & & \\
AGCT & 2.4 & 3.0 & & \\
AGTC & 0.9 & 0.6 & & \\
AGTT & 0.9 & 0.0 & & \\
GACT & 0.6 & 0.0 & & \\
GATC & 32.0 & 31.3 & \\
GATT & 6.8 & 7.5 & \\
GGCC & 2.7 & 3.3 & & \\
GGCT & 7.8 & 9.6 & & \\
GGTC & 5.6 & 6.6 & & \\
GGTT & 40.0 & 36.8 & 4.489 & 0.8975 \\
\hline
\end{tabular}

Haplotypes are constructed out of polymorphic sites at IVS4 + $71 \mathrm{G} \rightarrow \mathrm{A}, 1264 \mathrm{G} \rightarrow \mathrm{A}$, IVS20 $+17 \mathrm{~T} \rightarrow \mathrm{C}$ and IVS23 $+24 \mathrm{~T} \rightarrow \mathrm{C}$ (left to right). Haplotype counts were calculated from estimated haplotype frequencies. Hence, deviations between tables 5 and 6 may be the result of imprecise rounding.

\section{Discussion}

The elastin gene is a major candidate gene in the pathogenesis of IA, for several reasons: elastin is an elementary component of the ECM and the internal elastic lamina, thus contributing to the structural integrity and determining elastic strength of the vessel wall. Remodeling of the ECM seems to be a process that is fundamental to aneurysm development [5], and the internal elastic lamina is frequently altered by defects or has degenerated in IA [20]. Experimental IA can be induced by the application of elastase, which specifically degrades elastin molecules [9], or by the inhibition of cross-linkage between elastin molecules [21]. Finally, the first genome-wide linkage study among IA patients, which was performed by Onda et al. [12], identified a link between the elastin locus and IA in a Japanese population. Therefore, in view of the morphological and experimental evidence we cannot avoid the hypothesis that alterations of the elastin molecule contribute to IA development in humans and that this process is not dependent on ethnicity.

However, differences in haplotype frequencies between Japanese and Caucasian populations have been described for the mucopolysaccharidosis IVA gene in a study by Rezvi et al. [22] and, more recently, for the angiotensinogen gene [23]. In the latter study, Nakajima et al. [23] performed a sequence analysis of the angiotensinogen genomic region in 88 unselected Caucasian and 77 unselected Japanese subjects. They identified 44 SNPs and searched for pairwise linkage disequilibrium measured by the $\mathrm{D}^{\prime}, \mathrm{r}(2)$, and d(2) statistics. Although the two populations were found to share all of 6 major angiotensinogen haplotypes, there were substantial differences between them in haplotype frequencies.

We did not analyze the entire elastin gene in our study, but 8 out of 14 SNPs identified by Onda et al. [12]. Genetic variants in the promoter region might have an impact on transcriptional activity, and SNPs in the coding region leading to an amino acid exchange may alter the physical and biochemical properties of a protein, although, to our knowledge, there are no data published proving a functional impact of these particular elastin SNPs. Therefore, it is suggested that these SNPs might have an effect on the phenotype. However, we could not find an association between genotype frequencies and the occurrence of intracranial aneurysms.

In our study, we found allele frequencies in 4 out of 8 SNPs that were significantly different from those reported to occur in the unaffected Japanese population. Interestingly, these differences are most prevalent in the $5^{\prime}$ region of the gene. While there is a highly significant difference between Caucasian and Japanese allele frequencies of SNPs located in the promoter, SNPs located in intron 4 and exon 20 are still significantly different, but with declining levels of significance. Finally, the allele frequency of the intron 20 and intron 23 SNPs is almost the same in both ethnic groups. This leads us to speculate about whether these findings might be connected with the genomic structure of the gene, which harbors more than 
$30 \mathrm{Alu}$ repeats with an abundance of these repetitive elements in the $3^{\prime}$ region, which, it has been suggested, increases the possibility of consequent polymorphism in the human population [24]. Alu repeats have been associated with recombination events in the elastin gene [25] and with genome instability [26], which might explain interindividual and interracial differences. This oppositeness might be interpreted by the hypothesis that during evolution, recombination at the $3^{\prime}$ end of the gene including the $3^{\prime}$ UTR might have resulted in a stable gene product in primates while recombination at the $5^{\prime}$ end resulted in functional and interracial differences. However, in any study designed in an attempt to answer this question, a detailed sequence analysis of different ethnic groups, including functional tests of the SNP and haplotypes identified, would be mandatory.

Our results are in accordance with a very recent study, analyzing the IVS20 $+17 \mathrm{~T} \rightarrow \mathrm{C}$ and IVS2 $3+24 \mathrm{~T} \rightarrow \mathrm{C}$ polymorphism in a mixed European population consisting of patients with familial and sporadic IA and controls.
In that study, no association, neither between these elastin polymorphisms nor the estimated haplotype frequencies and the occurrence of IA, was found [27].

In conclusion, we failed to show an association between SNPs or haplotypes of the elastin gene and the occurrence of IA in our Caucasian populations. These data are not in line with our hypothesis that alterations of the elastin gene contribute to IA development in humans independently of ethnicity, as we provide further evidence for the impact of racial/ethnic differences on the association of genetic variants with a phenotype.

\section{Acknowledgements}

This study was in part supported by a grant from the Deutsche Forschungsgemeinschaft, No. 1538/3-1. We would like to thank Mrs U. Neumeister for her outstanding technical assistance and Mrs J. Dodsworth for her help in preparing the manuscript.

\section{References}

1 Inagawa T: Trends in incidence and case fatality rates of aneurysmal subarachnoid hemorrhage in Izumo City, Japan, between 1980 1989 and 1990-1998. Stroke 2001;32:1499_ 1507.

2 Weir BK, Kongable GL, Kassell NF, Schultz JR, Truskowski LL, Sigrest A: Cigarette smoking as a cause of aneurysmal subarachnoid hemorrhage and risk for vasospasm: A report of the Cooperative Aneurysm Study. J Neurosurg 1998;89:405-411.

3 Teunissen LL, Rinkel GJ, Algra A, van Gijn J: Risk factors for subarachnoid hemorrhage: A systematic review. Stroke 1996;27:544-549.

4 Juvela S, Hillbom M, Numminen H, Koskinen $\mathrm{P}$ : Cigarette smoking and alcohol consumption as risk factors for aneurysmal subarachnoid hemorrhage. Stroke 1993;24:639-646.

5 Bruno G, Todor R, Lewis I, Chyatte D: Vascular extracellular matrix remodeling in cerebral aneurysms. J Neurosurg 1998;89:431-440.

6 Yamazoe N, Hashimoto N, Kikuchi H, Kang Y, Nakatani H, Hazama F: Study of the elastic skeleton of intracranial arteries in animal and human vessels by scanning electron microscopy. Stroke 1990;21:765-770.

7 Peters DG, Kassam AB, Feingold E, HeidrichO'Hare E, Yonas H, Ferrell RE, Brufsky A: Molecular anatomy of an intracranial aneurysm: Coordinated expression of genes involved in wound healing and tissue remodeling. Stroke 2001;32:1036-1042.
8 Miskolczi L, Guterman LR, Flaherty JD, Hopkins LN: Saccular aneurysm induction by elastase digestion of the arterial wall: A new animal model. Neurosurgery 1998;43:595-600, discussion 600-601.

9 Miskolczi L, Guterman LR, Flaherty JD, Szikora I, Hopkins LN: Rapid saccular aneurysm induction by elastase application in vitro. Neurosurgery 1997;41:220-228, discussion 228229.

10 Kallmes DF, Fujiwara NH, Berr SS, Helm GA, Cloft HJ: Elastase-induced saccular aneurysms in rabbits: A dose-escalation study. AJNR Am J Neuroradiol 2002;23:295-298.

11 Coutard M: Experimental cerebral aneurysms in the female heterozygous Blotchy mouse. Int J Exp Pathol 1999;80:357-367.

12 Onda H, Kasuya H, Yoneyama T, Takakura K, Hori T, Takeda J, Nakajima T, Inoue I: Genomewide-linkage and haplotype-association studies map intracranial aneurysm to chromosome 7q11. Am J Hum Genet 2001;69:804819.

13 Krex D, Ziegler A, Schackert HK, Schackert G: Lack of association between endoglin intron 7 insertion polymorphism and intracranial aneurysms in a white population: Evidence of racial/ethnic differences. Stroke 2001;32:26892694.
14 Ameyaw MM, Regateiro F, Li T, Liu X, Tariq M, Mobarek A, Thornton N, Folayan GO, Githang'a J, Indalo A, Ofori-Adjei D, Price-Evans DA, McLeod HL: MDR1 pharmacogenetics: Frequency of the C3435T mutation in exon 26 is significantly influenced by ethnicity. Pharmacogenetics 2001;11:217-221.

15 Crawford DC, Schwartz CE, Meadows KL, Newman JL, Taft LF, Gunter C, Brown WT, Carpenter NJ, Howard-Peebles PN, Monaghan KG, Nolin SL, Reiss AL, Feldman GL, Rohlfs EM, Warren ST, Sherman SL: Survey of the fragile X syndrome CGG repeat and the shorttandem-repeat and single-nucleotide-polymorphism haplotypes in an African American population. Am J Hum Genet 2000;66:480-493.

16 Wittwer CT, Ririe KM, Andrew RV, David DA, Gundry RA, Balis UJ: The LightCycler: A microvolume multisample fluorimeter with rapid temperature control. Biotechniques 1997;22:176-181.

17 Ririe KM, Rasmussen RP, Wittwer CT: Product differentiation by analysis of DNA melting curves during the polymerase chain reaction. Anal Biochem 1997;245:154-160.

18 Excoffier L, Slatkin M: Maximum-likelihood estimation of molecular haplotype frequencies in a diploid population. Mol Biol Evol 1995;12: 921-927.

19 den Dunnen JT, Antonarakis SE: Nomenclature for the description of human sequence variations. Hum Genet 2001;109:121-124. 
20 Stehbens W: Histopathology of cerebral aneurysms. Arch Neurol 1963;8:272-285.

21 Gaetani P, Grazioli V, Tancioni F, Casari E, Tartara F, Rodriguez y Baena R: Abnormalities of collagen cross-linkage in posterior communicating artery aneurysms: A preliminary study. Neurol Res 1996;18:541-545.

22 Rezvi GM, Tomatsu S, Fukuda S, Yamagishi A, Cooper A, Wraith JE, Iwata H, Kato Z, Yamada N, Sukegawa K, Shimozawa N, Suzuki Y, Kondo N, Orii T: Mucopolysaccharidosis IVA: A comparative study of polymorphic DNA haplotypes in the Caucasian and Japanese populations. J Inherit Metab Dis 1996;19. 301-308.
23 Nakajima T, Jorde LB, Ishigami T, Umemura S, Emi M, Lalouel JM, Inoue I: Nucleotide diversity and haplotype structure of the human angiotensinogen gene in two populations. Am J Hum Genet 2002;70:108-123.

24 Indik Z, Yoon K, Morrow SD, Cicila G, Rosenbloom J, Ornstein-Goldstein N: Structure of the $3^{\prime}$ region of the human elastin gene: Great abundance of Alu repetitive sequences and few coding sequences. Connect Tissue Res 1987; 16:197-211.

25 Szabo Z, Levi-Minzi SA, Christiano AM, Struminger C, Stoneking M, Batzer MA, Boyd CD: Sequential loss of two neighboring exons of the tropoelastin gene during primate evolution. J Mol Evol 1999;49:664-671.
26 Calabretta B, Robberson DL, Barrera-Saldana HA, Lambrou TP, Saunders GF: Genome instability in a region of human DNA enriched in Alu repeat sequences. Nature 1982;296:219225.

27 Hofer A, Hermans M, Kubassek N, Sitzer M, Funke H, Stögbauer F, Ivaskevicius V, Oldenburg J, Burtscher J, Knopp U, Schoch B, Wanke I, Hübner F, Deinsberger W, Meyer B, Boecher-Schwarz H, Poewe W, Raabe A, Steinmetz H, Auburger G: Elastin polymorphism haplotype and intracranial aneurysms are not associated in central Europe. Stroke 2003;34: 1207-1211 